\title{
The Legislative Injunction: A Remedy for Unconstitutional Legislative Inaction
}

\author{
Robert A. Schapiro
}

The growth of structural litigation, in which Federal judges mandate basic reordering of bureaucratic institutions, has occasioned increasing conflicts between courts and legislatures. ${ }^{1}$ To implement their remedial goals, institutional reform decrees frequently require increased appropriations, ${ }^{2}$ the promulgation of new enabling legislation, ${ }^{3}$ or some other kind of affirmative legislative performance. ${ }^{4}$ Legislators often resist these intrusions into what they conceive as their legitimate realm of discretion, refusing to act in accordance with the judicial plan.

To prod legislatures into cooperation, courts have employed various means, such as moral suasion or, in certain cases, the threat to close down the offending institution. ${ }^{5}$ When these methods prove ineffective, courts may find themselves unable to implement their decrees. Recently, however, some courts have adopted more intrusive measures to overcome legislative intransigence. This Term, the Supreme Court will review two circuit court decisions, Jenkins v. Missouri ${ }^{6}$ and United States v. City of Yonkers, ${ }^{7}$ which approved especially bold judicial initiatives in the face of legislative resistance.

In Yonkers the Court will consider Judge Leonard Sand's efforts to

1. See Hanson, Contending Perspectives on Federal Court Efforts to Reform State Institutions, 59 U. Colo. L. REv. 289 (1988); Johnson, The Role of the Federal Courts in Institutional Litigation, 32 ALA. L. REV. 271 (1981); Starr, Accommodation and Accountability: A Strategy for Judicial Enforcement of Institutional Reform Decrees, 32 Ala. L. Rev. 399 (1981).

2. Funding is almost always an issue in structural litigation. For a recent example, see Jenkins v. Missouri, 855 F.2d 1295 (8th Cir. 1988) (approving order of $\$ 260$ million capital expenditure plan for purpose of school desegregation), cert. granted, 109 S. Ct. 1930 (1989).

3. See, e.g., United States v. Yonkers Bd. of Educ., 635 F. Supp. 1577 (S.D.N.Y. 1986) (requiring amendment of zoning ordinance and construction of housing), affd, 837 F.2d 1181 (2d Cir. 1987), cert. denied, 108 S. Ct. 2821 (1988).

4. See, e.g., United States v. City of Parma, 504 F. Supp. 913 (N.D. Ohio 1980) (requiring city to enact resolution welcoming people of all races), affd in relevant part, $661 \mathrm{~F} .2 \mathrm{~d} 562$ (6th Cir. 1981), cert. denied, 456 U.S. 926 (1982).

5. See Frug, The Judicial Power of the Purse, 126 U. PA. L. REv. 715, 791 (1978) (emphasizing importance of court's power to declare conditions illegitimate); Hirschhorn, Where the Money is: Remedies to Finance Compliance with Strict Structural Injunctions, 82 MICH. L. Rev. 1815, 1849-51 (1984) (discussing court's option to close institution). Threats of closure prove effective only when the institution is one that the court can credibly shut and that the legislature has a compelling interest in keeping open. Prisons are probably the best example of this combination. See Id. at 1850-51.

6. 855 F.2d 1295 (8th Cir. 1988), cert. granted, 109 S. Ct. 1930 (1989).

7. 856 F.2d 444 (2d Cir. 1988), cert. granted sub nom. Spallone v. United States, 109 S. Ct. 1337 (1989). 
implement a remedy for segregation in schooling and housing in Yonkers, New York. After protracted litigation, extending over eight years, Judge Sand ordered members of the City Council, on pain of fine and imprisonment, to enact legislation required by a consent decree. ${ }^{8}$ When the Council rejected the legislation, Judge Sand imposed the penalties on the Gouncil members who voted against the legislation, and the Second Circuit affirmed. ${ }^{9}$ The Supreme Court stayed the contempt orders ${ }^{10}$ and subsequently agreed to review the sanctions. ${ }^{11}$

Jenkins concerns the means employed by Judge Russell Clark to finance a school desegregation plan in Kansas City, Missouri. When the school district failed to obtain funding for a court-ordered desegregation plan, Judge Clark ordered an increase in the local property tax and imposed a surtax on the state income tax for income earned within the district. ${ }^{12}$ While the Eighth Gircuit overturned the income tax order, finding it too great a break from existing methods of school finance, it affirmed the property tax surcharge. ${ }^{13}$

8. United States v. Yonkers Bd. Of Educ., No. 80-6761 (S.D.N.Y. July 26, 1988) (order detailing contempt penalties for not approving required legislation), affd sub nom. United States v. City of Yonkers, 856 F.2d 444 (2d Cir. 1988), cert. denied, 109 S. Ct. 1339 (1989) (contempt sanctions against City of Yonkers), cert. granted sub nom. Spallone v. United States, 109 S. Ct. 1337 (1989) (contempt sanctions against individual council members). The underlying constitutional violations that Judge Sand sought to remedy are described in great detail in his original opinion, which found liability for intentional discrimination in schooling and housing. See United States v. Yonkers Bd. of Educ., 624 F. Supp. 1276 (S.D.N.Y. 1985), affd, 837 F.2d 1181 (2d Cir. 1987), cert. denied, 108 S. Ct. 2821 (1988).

9. United States v. Yonkers Bd. of Educ., No. $80-6761$ (S.D.N.Y. Aug. 2, 1988) (finding Council members Chema, Fagan, and Longo in contempt); United States v. Yonkers Bd. of Educ., No. 806761 (S.D.N.Y. Aug. 5, 1988) (finding Council member Spallone in contempt retroactive to Aug. 2, 1988), aff'd sub nom. United States v. City of Yonkers, 856 F.2d 444 (2d Cir. 1988), cert. granted sub nom. Spallone v. United States, 109 S. Ct. 1337 (1989). Judge Sand also levied contempt fines against the City of Yonkers which began at one dollar and doubled each day. United States v. Yonkers Bd. of Educ., No. 80-6761 (S.D.N.Y. Aug. 2, 1988) (finding City of Yonkers in contempt). The Second Circuit affirmed these fines as well, although it ruled that they should double only until reaching one million dollars per day and then continue at that level until the required legislation was adopted. United States v. City of Yonkers, 856 F.2d 444 (2d Cir. 1988), cert. denied, 109 S. Ct. 1339 (1989).

10. Spallone v. United States, 109 S. Ct. 14 (1988).

11. Spallone v. United States, 109 S. Ct. 1337 (1989). The Court granted certiorari even though in the face of bankrupting fines against the City of Yonkers, which the Supreme Court refused to stay, the Council members eventually did pass the required resolution. The Council members each paid a total of $\$ 3500$ in contempt fines for the period between the contempt order on August 2, 1988 and the Second Circuit's stay on August 9, 1988. See Petition for a Writ of Certiorari to the United States Court of Appeals for the Second Circuit at A194n-A195n, In re Spallone, No. 88-854 (U.S. filed Nov. 23, 1988); Brief for Petitioner Spallone at 8, Spallone v. United States, 109 S. Ct. 1137 (1989) (No. 88-854), granting cert. to 856 F.2d 444 (2d Cir. 1988); Brief for Petitioner at 16, Chema v. United States, 109 S. Ct. 1137 (1989) (No. 88-856), granting cert. to 856 F.2d 444 (2d Cir. 1988). At the contempt hearing, Judge Sand ordered the Council members imprisoned if the resolution was not passed by August 10, 1988. Because of subsequent stays by the Second Circuit and the Supreme Court, the Council members were not actually imprisoned for contempt.

12. Jenkins v. Missouri, 672 F. Supp. 400 (W.D. Mo. 1987), affd in part, rev'd in part, 855 F.2d 1295 (8th Cir. 1988), cert. granted, 109 S. Ct. 1930 (1989). Judge Clark imposed the taxes directly, without legislative action, and ordered state and county tax officials to collect them. $672 \mathrm{~F}$. Supp. at 412-13.

13. 855 F.2d 1295 (8th Cir. 1988), cert. granted, 109 S. Ct. 1930 (1989). 
These cases illustrate two related approaches to overcoming legislative obstruction. The court can either order legislators to enact certain bills or can circumvent the legislative process and create legislation by judicial decree. Both of these options entail a court's apparent arrogation of traditionally legislative authority; both substitute the judge's decision as to the positive content of the law for that of the legislature. This Note terms a court order that serves to create legislation without any intervening legislative discretion a "legislative injunction." A legislative injunction either compels, or substitutes for, the enactment of a specific bill. ${ }^{14}$ This Note considers the use of the legislative injunction as a means to counteract unconstitutional legislative inaction. ${ }^{15}$

Courts have become accustomed to nullifying unconstitutional legislative action through the mechanism of judicial review. Counteracting unconstitutional legislative inaction through a legislative injunction, however, appears to be a much greater violation of legislative prerogative. As the City Council members argued in Yonkers, a court's threat to jail legislators unless they vote for a particular bill seems at odds with well established principles of legislative privilege. ${ }^{16}$ Similarly, a court's assumption of the taxing power appears to be an arrogation of traditionally legislative authority. ${ }^{17}$

This Note argues that the legislative injunction is a legitimate exercise of judicial authority, indeed as legitimate as a court's overturning unconstitutional legislation through judicial review. The legislative injunction accords with the understanding of the legislative role as deciding on the general distribution of rights and resources and the judicial role as ensur-

14. Structural injunctions often substitute for legislative action in the sense that the remedies they mandate could also have been enacted by a legislative body. Changing prison conditions or regulating mental health care, for example, lie within the scope of the legislative power. However, the activities that the court wishes to reform normally come under the routine supervision of administrative bodies, and it is with these kinds of administrative operations that the court's order is normally concerned. By contrast, the legislative injunction, as discussed in this Note, involves functions centrally identified with legislative bodies, functions such as enacting legislation or raising funds that do not lend themselves to administrative delegation.

15. This Note will limit its focus to use of the legislative injunction by Federal courts against state and local legislatures, which is the most common framework for structural litigation. The Note will not examine the use of legislative injunctions by state courts, nor will it consider the special concerns implicated in directing judicial decrees at the United States Congress.

16. See, e.g., Brief for Petitioner Spallone at 19-41, Spallone v. United States, 109 S. Ct. 1137 (1989) (No. 88-854), granting cert. to 856 F.2d 444 (2d Cir. 1988); Brief for Petitioner at 24-32, Chema v. United States, 109 S. Ct. 1137 (1989) (No. 88-856), granting cert. to 856 F.2d 444 (2d Cir. 1988).

The imprisonment of legislators for violating a judicial order as to how to vote on a bill is not wholly unprecedented. In 1882 a judge jailed fifteen Brooklyn aldermen for voting, in defiance of a court order, to override a mayoral veto of a change in the route of an elevated railway then under construction. See People ex rel. Negus v. Dwyer, 1 Civ. Proc. Rep. 484, 486 (N.Y. Sup. Ct.), affd, 90 N.Y. 402 (1882); Richland, City of Brooklyn Aldermen and the Yonkers Councilmen, N.Y.L.J., Sept. 15, 1988, at 3, col. 1.

17. See Note, An Unorthodox Usurpation of Legislative Power in Jenkins v. Missouri, 21 Creighton L. Rev. 1269, 1286 (1988) (criticizing judge's levying tax as leading to "unconscionable realignment of control between the legislative and judicial branches of government"). 
ing that this allocation is accomplished fairly, without prejudicing the rights of particular groups or individuals. The legislative injunction responds to a situation, such as a segregated school or an inhumane prison, in which legislative inaction will cause a deprivation of constitutional rights. By mandating a particular action, the court assures that the legislature cannot exercise its "discretion" not to act and thereby impair individuals' constitutional rights. This role for the court in defining the bounds of legislative discretion falls squarely within the traditional understanding of judicial authority.

Nor does the legislative injunction conflict with legislative immunity doctrine. In deciding the proper scope of legislative immunity, courts have developed an understanding of the proper domain of discretion in order to distinguish those acts of legislators that are truly "legislative," hence shielded by immunity, from those that are "non-legislative" and do not enjoy this protection. Building on this distinction, the Note finds the legitimacy of legislative injunctions well grounded in immunity law principles. By their very nature, legislative injunctions usurp no legitimate legislative power. Instead they give expression to the evolving constitutional boundaries of legislative discretion, refusing to treat inaction as a privileged exercise of legislative authority. By contrast, a formal view of legislative prerogative which rejects the legislative injunction declares that not the Constitution, but the status quo, is supreme.

Section I explores the need for legislative injunctions and examines prior court decisions addressing the confrontation of legislatures and courts in structural litigation. Section II considers the development of legislative immunity doctrine with particular attention to the policy/implementation and the discretionary/ministerial distinctions that have developed in legislative immunity law. Section III expands on these immunity doctrines to develop a theory of legislative injunctions as tools to ensure that legislators do not deprive individuals of constitutional rights by failing to perform constitutionally mandated duties.

\section{Legislative Resistance and Judicial Reaction}

Although Federal courts enjoy broad equitable powers to fashion remedies for constitutional violations, ${ }^{18}$ they may have difficulty implementing their decrees without the compliance of state and local legislatures. The most common area in which legislative assistance is required is in the financing of remedial orders. Whether they seek to improve prison conditions, reform mental hospitals, or desegregate schools, structural remedies inevitably involve increased spending, and the appropriation power has a strong historical and constitutional tie to the legislature. ${ }^{19}$ Remedial orders

18. See Swann v. Charlotte-Mecklenburg Bd. of Educ., 402 U.S. 1, 15 (1971).

19. The Constitution commits the Federal appropriation power to the legislature and, specilically, 
may also require other kinds of enabling acts, such as zoning changes, which are within the traditionally legislative sphere of authority. Whether based on principled disagreement or mere parsimony, legislatures are not always willing to enact the necessary legislation.

When courts have come into conflict with legislatures, the Supreme Court has generally refused to allow claims of autonomy to prevent the implementation of constitutional remedies. Since Brown v. Board of Education, ${ }^{20}$ conflicts between courts and legislatures have often arisen in the context of school desegregation decisions. The Supreme Court has suggested that courts may indeed order local bodies to levy taxes if necessary to ensure compliance with a prior remedial order. When a school board in Prince Edward County, Virginia, closed the public schools to avoid a desegregation decree, while providing tax incentives to private, segregated schools, the Court in Griffin v. County School Board ${ }^{21}$ stated that the district court could order the school supervisors to levy the taxes required to re-open the schools and to run them without racial discrimination. ${ }^{22}$

The lower Federal courts have disagreed on how broadly to interpret the Supreme Court's warrant for interfering in local taxing decisions. ${ }^{23}$ Generally, courts have insisted that judges show all possible deference to local revenue processes, intervening only as a last resort. In Evans $v$. Buchanan, ${ }^{24}$ for example, the Third Circuit reviewed a judge's decision overturning a legislatively-established tax rate that he believed inadequate to fund a desegregation remedy. While not reaching the merits of the district court's order, the Third Circuit granted a writ of mandamus vacating the order and requiring a new hearing on the grounds that the lower court refused to give a presumption of constitutionality to the legislative action. The Third Circuit objected to the district judge's failing to show "the requisite deference to which legislative judgments in the field of taxation are entitled."2s

When alternatives have been exhausted, courts have used Griffin to justify ordering tax increases. The Eighth Circuit has been particularly will-

to the chamber closest to the people. U.S. ConsT. art. I, \$\$ 7-8; see Stith, Congress' Power of the Purse, 97 Yale L.J. 1343 (1988). In the state context, the Supreme Court has recognized the close connection of the taxing power to the state legislature. See Green v. Frazier, 253 U.S. 233 (1920); Comment, Liddell v. Missouri: Financing the Ancillary Costs of Public School Desegregation Through a Court-Ordered Tax Increase, 42 WASH. \& LEE L. REv. 269 (1985).

20. 347 U.S. 483 (1954).

21. 377 U.S. 218 (1964).

22. Id. at 233. Since an order to levy taxes was not yet necessary, the proposition that the district caurt had a right to issue such an order could be considered dictum, but nothing in the opinion suggested that this aspect of the ruling was speculative or purely hypothetical. The lower courts never had occasion actually to force the Board to levy taxes, but did direct the Board to recoup private tuition grants made in violation of a court order. See Griffin v. County School Bd., 363 F.2d 206 (4th Cir.), cert. denied, 385 U.S. 960 (1966).

23. See Comment, supra note 19, at 277-82; Note, Judicial Taxation in Segregation Cases, 89 Colum. L. Rev, 332, 332-37 (1989).

24. 582 F.2d 750 (3d Cir. 1978) (en banc), cert. denied, 446 U.S 923 (1980).

25. Id. at 778 . 
ing to sanction court-ordered taxation. ${ }^{26}$ In United States $v$. Missouri ${ }^{27}$ the Eighth Circuit reviewed a district judge's decision to impose a tax when he believed local authorities would not approve the necessary funding measures. While reversing the particular plan as potentially unnecessary, the court indicated approval for the notion of a judicially imposed tax. ${ }^{28}$ In Liddell v. Missouri, ${ }^{29}$ a decision on which Judge Clark relied heavily in Jenkins, ${ }^{30}$ the Eighth Circuit reiterated its interpretation of Griffin as authorizing courts to order tax increases in the absence of fiscal alternatives. In Liddell the court found support for its holding both in Griffin and in the case law surrounding the contracts clause, ${ }^{31}$ an area in which Federal courts have long had occasion to intervene in local taxing and spending decisions. ${ }^{32}$

The Supreme Court has also made clear that general principles of state sovereignty will not be allowed to block the implementation of constitutional remedies. In Milliken v. Bradley ${ }^{33}$ the Court established that a state itself, if found responsible for school segregation, could be required to help fund the remedy. By holding that neither the Tenth Amendment nor the Eleventh Amendment would shield states from liability for prospective relief, ${ }^{34}$ the Court reaffirmed that Federal judges need not allow deference to non-Federal government structures to impede the implementation of remedial orders. ${ }^{35}$

An important prerequisite for all judicial intrusions into local legislative decisions, especially those concerning tax policy, has been the determination of a constitutional violation. Courts have been wary of coercing legis-

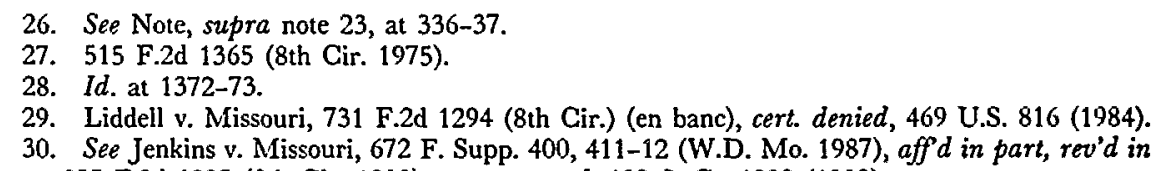
part, 855 F.2d 1295 (8th Cir. 1988), cert. granted, 109 S. Ct. 1930 (1989).

31. "No State shall . . pass any ... Law impairing the Obligation of Contracts . . ." U.S. CoNST. art. I, $\$ 10$, cl. 1.

32. The Liddell court specifically relied on Louisiana ex rel. Hubert v. Mayor of New Orleans, 215 U.S. 170 (1909), in which the Supreme Court held that a court could order a city to levy and collect a tax for the benefit of creditors who had been promised the tax revenues. The City of New Orleans had attempted to avoid honoring a judgment that resulted from a contractual obligation to pay certain tax revenues to the metropolitan police board. The Supreme Court ruled that the city could be requirtd "to pay over the taxes for which the judgment was rendered, or to levy and collect a tax therefor." 215 U.S. at 181.

33. 433 U.S. 267 (1977).

34. See id. at $288-91$.

35. The Court has ruled that separation of powers constraints apply only to the relationship between coordinate branches of government, not to conflicts between Federal courts and state governments. See Elrod v. Burns, 427 U.S. 347 (1976) (plurality opinion); see also Jenkins v. Missouri, 855 F.2d 1295 (8th Cir. 1988) (finding separation of powers principle inapplicable to court-ordered tax levy), cert. granted, 109 S. Ct. 1930 (1989). Further, the Court has indicated that the immunity that the Eleventh Amendment grants is available only to a state government, not to a local political subdivision. See Edelman v. Jordan, 415 U.S. 651, 666 n.12 (1974); Lincoln County v. Luning, 133 U.S. $529,530(1890)$. For a criticism of the Supreme Court's refusal to use separation of powers principles to limit Federal courts' intervention into state governments' activities, see Nagel, Separation of Powers and the Scope of Federal Equitable Remedies, 30 STAN. L. REv. 661 (1978). 
lative cooperation in implementing a remedy resulting from a consent judgment, rather than from a finding of liability. ${ }^{36}$ This general judicial reluctance to enforce consent judgments becomes particularly pronounced when the legislature is not a formal party to the settlement. In these circumstances courts are hesitant to impute an affirmative duty to the legislature to fund the agreed upon measures.

Despite a consent judgment entered into by the Governor of New York, for example, the state legislature refused to provide funding for a plan to remedy unconstitutional conditions at the Willowbrook mental institution. ${ }^{37}$ The Second Circuit ruled that the district court could not coerce compliance by holding the Governor and Comptroller in contempt. ${ }^{38}$ The district court apparently did not attempt to order legislative compliance directly, but the Second Circuit opinion seemed to foreclose such an action, warning that a court should not put itself " in the difficult position of trying to enforce a direct order . . . to raise and allocate large sums of money, . . . steps traditionally left to appropriate executive and legislative bodies responsible to the voters." "38 The court stressed its belief that the legislature was not guilty of a constitutional violation and therefore was not subject to the broad remedial power of the court. ${ }^{40}$ The Second Circuit reached this conclusion despite the long history of horrendous conditions at the state-run Willowbrook facility. The Second Circuit thus tacitly blessed a pas de deux in which the Governor claimed that legislative inaction rendered his compliance impossible, while the legislature had no affirmative obligation to facilitate an agreement to which it was not a formal party.11

In Brewster v. Dukakis, ${ }^{42}$ the First Circuit similarly limited the ability of the district court to implement a consent decree concerning the provision of mental health services. When the legislature refused to fund the program that the Governor had promised in the consent decree, the First Gircuit stated that the district court had no remedy against the legislature and that, in seeking to fund the program, the district court could not go beyond requiring the executive to exercise the "best efforts" demanded by the consent decree. ${ }^{43}$ District courts have faced analogous restrictions in

\footnotetext{
36. See Fiss, Against Settlement, 93 YALE L.J. 1073, 1084 (1984).

37. For a description of the conditions at Willowbrook and the prolonged litigation seeking to remedy them, see D. Rothman \& S. Rothman, The Willowbrook Wars (1984).

38. See New York State Ass'n for Retarded Children v. Carey, 631 F.2d 162 (1980).

39. 631 F.2d at 165 (quoting Rhem v. Malcolm, 507 F.2d 333, 341 (2d Cir. 1974)).

40. Id. at 166. But see Delaware Valley Gitizens' Council for Glean Air v. Pennsylvania, 678 F.2d 470 (3d Cir.), cert. denied, 459 U.S. 969 (1982) (legislature's refusal to appropriate funds provides no defense to contempt citation against executive branch defendants for refusing to comply with consent decree).

41. The Governor's position gained further strength from the wording of the consent decree, which made executive action contingent on any legislative approval required under state law. 631 F.2d at 163.

42. 675 F.2d 1 (1st Cir. 1982).

43. Id. at 2 .
} 
trying to implement consent decrees to remedy unconstitutional prison conditions. ${ }^{44}$

In sum, when long-standing legislative inaction directly violates a court's remedial order issued after a finding of a constitutional violation, courts have generally assumed broad powers to force legislative compliance. When, instead, there has been no judicial determination of liability and the legislative inaction violates no direct judicial order, courts are wary of coercing legislative cooperation. This insistence on a formal declaration of liability represents judges' justifiable reluctance to arrogate apparently legislative functions without a clear determination of official dereliction of duty. An agreement between two parties may well not provide a sufficient foundation for ordering the enactment of a specific bill or for circumventing the legislature altogether. ${ }^{45}$ Courts have thus even been willing to arrogate part of the legislature's taxing and spending power, though only after a particular constitutional violation has received judicial definition. In their role as guarantors of constitutional rights, courts have found justification for altering the general principle that appropriations decisions must rest with the people's elected representatives.

\section{Legislative Immunity}

The doctrine of legislative immunity represents an area in which courts have been particularly sympathetic to claims of legislative autonomy. This Section argues, however, that the legislative injunction accords with existing legislative immunity doctrine, as well as with the justifications underlying the general policy of immunity for public officials. Indeed, legislative immunity decisions elaborate a functional definition of legislative conduct that provides support for a court's assertion of power through a legislative injunction. As the cases make clear, legislative immunity does not exempt all conduct by legislators from judicial scrutiny.

Legislative immunity doctrine in the United States rests on vestiges of English tradition, deference to the people's democratically elected representatives, and more general principles of official immunity. An inheritance of the struggles in England between the Crown and Parliament, ${ }^{46}$ legislative immunity has a long history in America. Most Colonial constitutions provided for legislative privilege, and that right was strongly defended as a sign of Colonial independence in the face of conflict with

44. See Jensen v. State Bd. of Tax Comm'rs, 763 F.2d 272 (7th Cir. 1985); Newman v. Graddick, 740 F.2d 1513 (11th Cir. 1984).

45. In this, as in other ways, settlements may be more difficult to enforce than adjudications on the merits. For a discussion of the problems inherent in settling institutional reform suits, see Fiss, supra note 36.

46. See C. Wittke, The History of English Parliamentary Privilege (1970). Wittke takes care to specify some of the peculiarly English factors underlying Parliamentary privilege, such as the Crown's control of the court system and the historical connection between Parliamentary privilege and the judicial function of the High Court of Parliament. See id. at 182-98. 
Crown governors. ${ }^{47}$ The Federal Constitution seeks to protect legislative independence by guaranteeing freedom from civil arrest ${ }^{48}$ and freedom of speech and debate ${ }^{49}$ to members of Congress. ${ }^{30}$ While the Constitution provides no specific immunity for state legislators, the Supreme Court held in Tenney v. Brandhove that state legislators enjoyed a common law immunity that shielded them from Federal civil rights suits. ${ }^{51}$ The Court found that Congress could not have intended to abrogate traditional legislative immunity when it enacted the civil rights legislation in the postCivil War era. ${ }^{\text {s2 }}$

In 1979, The Court extended this immunity to "regional" legislators. In Lake Country Estates v. Tahoe Regional Planning Agency, ${ }^{53}$ local property owners attempted to sue members of the governing board of the Tahoe Regional Planning Agency, alleging that a land use ordinance deprived them of the beneficial use of their property. The Court held that the members of the board of the bi-state agency were absolutely immune if they were acting in a legislative capacity. While the Court's opinion expressly left open the issue of extending a similar immunity to local legislators, ${ }^{54}$ its reasoning seemed to demand such an extension. The opinion emphasized the special status of legislative activity with little reference to its level of operation. ${ }^{55}$ Accordingly, the eight circuits that have since addressed the issue have found legislative immunity available to local officials. $^{\text {sB }}$

47. See M. Clarke, Parliamentary Privilege in the American Colonies (1943).

48. "They [Senators and Representatives] shall in all Cases, except Treason, Felony and Breach of the Peace, be privileged from Arrest during their Attendance at the Session of their respective Houses, and in going to and returning from the same ...." U.S. CoNST. art. I, § 6, cl. 1 .

49. "[F]or any Speech or Debate in either House, they [Members of Congress] shall not be questioned in any other Place." U.S. CoNST. art. I, \$ 6, cl. 1.

50. On the relationship of the speech or debate clause to English parliamentary privilege, see Cella, The Doctrine of Legislative Privilege of Speech or Debate: The New Interpretation as a Threat to Legislative Coequality, 8 Suffolk U.L. Rev. 1019 (1974); Reinstein \& Silverglate, Legislative Privilege and the Separation of Powers, 86 HARv. L. REv. 1113 (1973).

51. 341 U.S. 367,376 (1951). Brandhove, a critic of the California Senate Fact-Finding Committee on Un-American Activities, claimed that the committee and its chairman had deprived him of his civil rights through various acts of harassment. The Supreme Court ruled that the committee and its members were absolutely immune from such a suit, provided that they "were acting in the sphere of legitimate legislative activity." Id.

52. Justice Frankfurter expressed this view by way of a forceful rhetorical question: "Did Congress by the general language of its 1871 statute mean to overturn the tradition of legislative freedom achieved in England by Civil War and carefully preserved in the formation of State and National Governments here?" 341 U.S. at 376.

For a discussion of common law legislative immunity in suits brought under 42 U.S.C. $\S 1983$, see Eisenberg, Section 1983: Doctrinal Foundations and an Empirical Study, 67 CoRNELL L. REv. 482, 491-504 (1982); Comment, A New Perspective on Legislative Immunity in Section 1983 Actions, 28 UCLA L. REv. 1087 (1981) (rejecting function-based immunity and proposing balancing test). See generally Developments in the Law-Section 1983 and Federalism, 90 Harv. L. Rev. $1133,1197-1204$ (1977) (reviewing legislative, judicial, and prosecutorial immunity in $\S 1983$ actions).

53. 440 U.S. 391 (1979).

54. Id. at 404 n.26.

55. Id. at 405 .

56. See Haskell v. Washington Township, 864 F.2d 1266, 1277 (6th Cir. 1988); Aitchison v. 
The official immunity strain of legislative immunity is strong, with courts being primarily concerned that the exercise of legislative power not be hampered by threat of lawsuit. ${ }^{57}$ Justice Frankfurter explained in Tenney that legislative privilege was meant to protect the "public good," as fear of legal retribution might hamper the "uninhibited discharge" of legislative duty. ${ }^{58}$ Even claims of "unworthy purpose" should not defeat the privilege, Frankfurter argued, because the need to defend oneself in court would create a distraction from legislative business. ${ }^{50}$

The use of the legislative injunction in situations such as those in Yonkers and Jenkins poses no threat to general official immunity policies. In those cases, the legislative injunction followed a judicial finding that instrumentalities of the state government had violated the Constitution. Once a court has found the governmental body liable for unconstitutional practices, official immunity principles do not reach the conduct of officials who impede a judge's remedial orders. Defending themselves in court against aggrieved constituents might interfere with legislators' performance of their official duties, but answering to a Federal judge seeking to remedy a proven constitutional violation hardly impedes legitimate public functions.

General official immunity principles, however, do not fully express the special deference for legislators recognized in legislative immunity doctrine. The immunity that the Court has defined for legislators extends beyond that granted to other government officials. Most public officials are shielded only by a conditional, "good faith," immunity. Judges do enjoy absolute immunity, but only against claims for damages. Legislative immunity, on the other hand, covers claims for damages, injunctive and declaratory relief, and attorneys' fees. ${ }^{60}$

Even this broad doctrinal protection recognizes some limits on legislative independence. To qualify for immunity, an act must fall within the

Raffiani, 708 F.2d 96, 98-100 (3d Cir. 1983); Reed v. Village of Shorewood, 704 F.2d 943, 952-53 (7th Cir. 1983); Espanola Way Corp. v. Meyerson, 690 F.2d 827, 829 (11th Cir. 1982), cert. denied, 460 U.S. 1039 (1983); Kuzinich v. County of Santa Clara, 689 F.2d 1345, 1349-50 (9th Cir. 1982); Hernandez v. City of Lafayette, 643 F.2d 1188, 1193-94 (5th Cir. Unit A 1981), cert. denied, 455 U.S. 907 (1982); Bruce v. Riddle, 631 F.2d 272, 274-80 (4th Cir. 1980); Gorman Towers, Inc. v. Bogoslavsky, 626 F.2d 607, 611-14 (8th Cir. 1980).

57. For a discussion of the policy justifications underlying official immunity, see P. ScHUCK, SuING GovernMEnT 89-99 (1983).

58. Tenney, 341 U.S. at 377.

59. Id.

60. See Supreme Court of Va. v. Consumers Union, 446 U.S. 719 (1980); Schwartz, Legislative Immunity Developments, N.Y.L.J. Oct. 18, 1988, at 3, col. 1. The Supreme Court has affirmed this broad immunity for state legislators by analogy to the protection afforded to Congressmen and Senators by the speech or debate clause. See Supreme Court of Va., 446 U.S. at 733. State legislators thus benefit from the constitutional protection of Federal legislators, even though the Court has distinguished between the scope of Federal and state legislators' rights. See, e.g., United States v. Gillock, 445 U.S. 360 (1980) (refusing to extend evidentiary privilege guaranteed by speech or debate clause to state legislator in criminal trial). 
sphere of legitimate legislative activity. ${ }^{61}$ The Supreme Court has adopted a "functional" approach in addressing issues of official immunity, ${ }^{62}$ and courts have generally not been deferential to the formal appearance of legislative activity in defining the scope of local legislative immunity. ${ }^{63}$ In deciding questions of local legislative immunity in Federal civil rights cases, courts have often sought to determine whether an action is legislative, hence immunized, by reference to the underlying substantive issue, rather than to the nominal character of the decision-making body. Courts have limited legislative immunity to actions of a general, policy-setting nature. Legislators have not enjoyed immunity for decisions directed to a more particular, individualized result, especially when the action prejudices the rights of one specific individual or group.

In Cutting v. Muzzey, ${ }^{64}$ which concerned a town planning board's consideration of a subdivision plan, the First Circuit analyzed decisions by a local body based on the nature of the underlying facts and on the particularity of the impact. If the decision rested on general policy determinations and did not seek to single out individuals, then it was considered to be legislative. If the decision was more specific in purpose and effect, it was deemed not legislative, but administrative. Official decisions of the same body performed according to the same formal process could thus be legislative or non-legislative, depending upon the subject of the action.

Other courts have made a similar distinction between legislative acts which set public policy priorities and administrative actions which do not express the legislative prerogative to assert general policy goals. ${ }^{\mathrm{ES}}$ The dis-

61. See Tenney, 341 U.S. at 376.

62. See Forrester v. White, 108 S. Ct. 538, 542 (1988).

63. By contrast, in interpreting the scope of congressional immunity under the speech or debate clause, this "functional" approach has been employed with great deference. In Kilbourn v. Thompson, 103 U.S. 168 (1880), the Supreme Court held that congressional immunity applies to "things generally done in a session of the House by one of its members in relation to the business before it." Id. at 204. Thus, voting, see Powell v. McCormack, 395 U.S. 486 (1969), preparing and delivering speeches, see United States v. Johnson, 383 U.S. 169 (1966), and various investigative activities, see Eastland v. United States Servicemen's Fund, 421 U.S. 491 (1975), have been held to be absolutely protected without regard to the content of the action. In Kilbourn, the Court indicated that some congressional conduct might be so outrageous as to be unprotected by the speech or debate clause:

It is not necessary to decide here that there may not be things done, in the one House or the other, of an extraordinary character, for which the members who take part in the act may be held legally responsible. If we could suppose the members of these bodies so far to forget their high functions and the noble instrument under which they act as to imitate the Long Parliament in the execution of the Chief Magistrate of the nation, or to follow the example of the French Assembly in assuming the function of a court for capital punishment we are not prepared to say that such an utter perversion of their powers to a criminal purpose would be screened from punishment by the constitutional provision for freedom of debate.

103 U.S. at 204-05. The Court has apparently never invoked this "regicide-or-its-moral-equivalent" exception.

64. 724 F.2d 259 (1st Cir. 1984).

65. See, e.g., de Botton v. Marple Township, 689 F. Supp. 477 (E.D. Pa. 1988) (denial of zoning amendment administrative, not legislative, act); Altaire Builders, Inc. v. Village of Horseheads, $551 \mathrm{~F}$. Supp. 1066 (W.D.N.Y. 1982) (denial of planned unit development application not legislative). But see Donivan v. Dallastown Borough, 835 F.2d 486 (3d Cir. 1987) (determining if act is legislative based on formal process of adoption), cert. denied, 108 S. Ct. 1596 (1988). For criticisms of Donivan, see 
trict court in Rateree $v$. Rockett $t^{68}$ summarized this line of local legislative immunity law: "[W]ell-established (if murky) doctrine indicates some legislative enactments, if they affect particular and not general interests, are 'administrative' and not 'legislative." "6r These cases recognize that not all actions a legislature takes come within the bounds of traditional legislative discretion. The legislative injunction develops the analogous principle that the failure to take certain actions also falls outside the realm of legitimate legislative prerogative.

The extent to which prior court action defining particular duties may transform a legislative into a non-legislative decision has not been addressed in recent immunity decisions. This issue did arise, though was not resolved, early in this century in Virginia $v$. West Virginia ${ }^{68}$ In this case, which came before the Supreme Court in its original jurisdiction, Virginia sought to have the Court force West Virginia to pay its share of the debt that existed before the states split. In its argument before the Court, Virginia asserted that since a judgment had been entered against West Virginia, the legislature of West Virginia had assumed a duty to take the steps necessary to appropriate the required funds. Although the Court could not compel the exercise of discretion, Virginia argued, the Court could order the performance of a non-discretionary task by the legislature. While the necessary action might appear to be within the protected sphere of legislative prerogative, in fact the legislature had an "absolute ministerial duty" preme Court contented itself with expressing the general right of Federal courts to enforce judgments against states, and subsequent compliance by West Virginia relieved the Court of the obligation to specify what kind of judicial order would be appropriate.

\section{The Legitimacy of Legislative Injunctions}

The premise of the legislative injunction is that the court has determined that the Constitution requires certain legislative actions and that the legislature has nevertheless refused to comply. Only when the legislature has failed to abide by a clear definition of a constitutional duty does the court take the step of directly ordering the legislature to enact a par-

Schwartz, supra note 60. See also Ditch v. Board of County Comm'rs, 650 F. Supp. 1245, 1249 (D. Kan. 1986) (discussing different tests for distinguishing between legislative and administrative acts); Developments in the Law-Zoning, 91 HARv. L. Rev. 1427, 1510-11 (1978) (discussing distinction between legislative and administrative acts in zoning context).

66. 630 F. Supp. 763 (N.D. Ill. 1986), affd, 852 F.2d 946 (7th Cir. 1988).

67. Id. at 770; see also Jodeco, Inc. v. Hann, 674 F. Supp. 488, 495-96 (D.N.J. 1987) (in suit challenging rezoning and denial of use variance, policy-setting Planning Board enjoys absolute immunity, policy-implementing Zoning Board does not); Ditch v. Board of County Comm'rs, 650 F. Supp. 1245,1250 (D. Kan. 1986) (abolition of employment position, unlike specific hiring decision, is absolutely immune since former "implicates policy decisionmaking").

68. 246 U.S. 565 (1918).

69. Id. at $572 \mathrm{n.1}$ (argument for petitioners). 
ticular bill or of circumventing the legislative process. The terms in which the Supreme Court has described the proper use of a Federal court's remedial power apply here, as well: "Judicial authority enters only when local authority defaults." Yonkers and in Jenkins illustrate the use of legislative injunctions as instruments of last resort.

\section{A. The Examples of Yonkers and Jenkins}

The extent of legislative defiance confronting Judge Sand in Yonkers was extreme. The underlying lawsuit had been filed more than seven years earlier, and almost three years had passed since he had found the City of Yonkers liable for intentional segregation in schooling and in housing. ${ }^{71}$ After prolonged resistance to a Housing Remedy Order entered by the court, ${ }^{72}$ the Gity Council had finally approved a consent decree in January $1988 .{ }^{73}$ The consent judgment included an agreement to adopt legislation providing for zoning changes. It was the refusal to enact this promised legislation that finally triggered the direct court order and, eventually, the imposition of contempt sanctions on the Council members who refused to vote in favor of the required resolution.

The Yonkers case represents the paradigmatic instance in which a legislative injunction infringes on no legitimate legislative prerogative. In response to a finding of constitutional violation, the City Council had previously agreed to enact the specific resolution that was the subject of Judge Sand's order. The City Council members had clearly already exercised all permissible discretion. The act of passing the zoning changes in these circumstances resembled more the ministerial performance of a well-defined legal obligation than the discretionary outcome of legislative deliberation. While the prior consent decree made the lack of legislative discretion particularly clear in this instance, in fact the discretion of state and local legislators is always limited by the requirements of the Constitution. ${ }^{74}$

In Jenkins, Judge Clark similarly resorted to a legislative injunction only after the regular political process had been exhausted. The Kansas City, Missouri School District had presented to the voters a bond issue and, on four separate occasions, a tax increase plan, but the voters rejected

70. Swann v. Charlotte-Mecklenburg Bd. of Educ., 402 U.S. 1, 16 (1971).

71. United States v. Yonkers Bd. of Educ., 624 F. Supp. 1276 (S.D.N.Y. 1985), affd, 837 F.2d 1181 (2d Cir. 1987), cert. denied, 108 S. Ct. 2821 (1988).

72. United States v. Yonkers Bd. of Educ., 635 F. Supp. 1577 (S.D.N.Y. 1986), affd, 837 F.2d 1181 (2d Cir. 1987), cert. denied, 108 S. Ct. 2821 (1988).

73. In Yonkers, unlike some of the suits discussed in Section $I$, the consent judgment concerned only the remedy phase of the litigation, which followed an adjudication of liability for constitutional violations.

74. The Constitution itself explicitly requires that state legislators pledge to abide by its dictates: "[T]he members of the several State Legislatures . . . shall be bound by Oath or Affirmation, to support this Constitution. . . ." U.S. CoNST. art. VI. 
each proposal. ${ }^{75}$ The state legislature had also refused to help the school district raise the necessary funds. ${ }^{76}$ It was following the failure of these conventional methods that Judge Clark imposed the tax directly, emphasizing that the court-ordered tax hike was only a measure of last resort. $\mathrm{He}$ stressed that he was "reluctant"77 to order a tax, but that the legislative and popular resistance left him with no choice, for "a majority has no right to deny others the constitutional guarantees to which they are entitled."78 In these circumstances, he believed that he had "no alternative but to impose tax measures." ${ }^{\prime \prime 9}$ Again, the Federal court intervened in the local governmental process after first clearly defining the constitutional requirements and allowing the legislature an opportunity to comply voluntarily.

The choice of a particular taxing scheme clearly does implicate larger policy concerns. However, given a finding of constitutional necessity, the legislature had discretion only to choose among various revenue schemes; it did not have discretion to adopt no fundraising plan. Judge Clark's decrees did not arrogate legislative authority, but rather sought to cabin legislative prerogative within constitutional bounds. The legislature had discretion to decide how to raise revenues, but not whether to do so. A variety of legislative alternatives conformed to the constitutional mandate, but some options did not, and one of these unacceptable actions was to do nothing at all..$^{80}$ By threatening to raise revenues himself, and finally ordering a tax, Judge Clark ensured that legislative inaction would not serve as an unreviewable mechanism for thwarting constitutional rights. By changing the background environment confronting the legislature, he transformed the extraordinary situation of a legislature's blocking a remedial order into the "normal" model of judicial review. Any action of the legislature was, as always, subject to judicial oversight, while legislative inaction presented no threat, since the status quo baseline (here, a courtordered tax hike) suffered from no constitutional infirmity. The legislature then had an allowable measure of discretion. By acting or failing to act, it chose between different proposals that did not offend constitutional principles. $^{81}$

75. See Jenkins v. Missouri, 672 F. Supp. 400, 411 (W.D. Mo. 1987), aff'd in part, rev'd in part, 855 F.2d 1295 (8th Cir. 1988), cert. granted, 109 S. Ct. 1930 (1989).

76. Id.

77. Id. at 412 .

78. Id.

79. Id.

80. Cf. San Antonio Indep. School Dist. v. Rodgriguez, 411 U.S. 1, 42 (1973) (quoting Jefferson

v. Hackney, 406 U.S. 535, 546-47 (1972)):

The very complexity of the problems of financing and managing a statewide public school system suggests that "there will be more than one constitutionally permissible method of solving them," and that, within the limits of rationality, "the legislature's efforts to tackle the problems" should be entitled to respect.

In Jenkins the legislature made essentially no effort to tackle the funding problem.

81. In Evans v. Buchanan, the district judge explicitly invited the legislature to alter the tax rate 
Judge Clark may not have arrived at the specific funding plan that both vindicated constitutional rights and best conformed to the legitimate policy goals of the legislature. ${ }^{82} \mathrm{~A}$ judge's inability to account for all the factors that a legislature would normally consider does imply that a legislative injunction has a policy "cost": The judge may not be able to pick the best, by any measure, of the constitutional alternatives available. However, an unwise judicial choice (or even the possibility of one) may spur a reluctant legislature into action. To the extent that legislative action in the first instance is preferable to a legislative injunction, for reasons of institutional competence, democratic accountability, and perhaps symbolic resonance, this kind of "penalty" default rule may even be desirable. ${ }^{83}$

\section{B. The Limits of the Legislative Injunction}

The legislative injunction, like judicial review, is counter-majoritarian in that it places the vindication of constitutional rights above the current will of the citizens and their representatives. Indeed, as an affirmative counter-majoritarian attack on a representative body, the legislative injunction may seem a doubly "deviant" institution in a democracy. ${ }^{84}$ In-

he had established, so long as the substituted rate provided sufficient funds for the desegregation remedy:

It is with deep seated reluctance overcome only be [sic] the pressing, immediate necessity and the realization that no other option is available to fill the legislative void that the Court becomes involved at all in matters of taxation. . . .

The Court is compelled, however, to order that a tax rate be established. This action is taken with the understanding that the Legislature can alter the parameters authorized. Because state political processes are preferred over even limited intervention by a Federal court, the Delaware Legislature may raise or lower the tax authorization established here.

Evans v. Buchanan, 447 F. Supp. 982, 1026 (D. Del.), affd in part, vacated in part, 582 F.2d 750 (3d Cir. 1978) (en banc), cert. denied, 446 U.S 923 (1980). The legislature proceeded to enact a tax rate that the court found inadequate. See supra text accompanying notes 24-25.

82. The Eighth Circuit's reversal of Judge Clark's income tax plan indicates that the substance of his order was at least open to reasonable disagreement. See Jenkins v. Missouri, 855 F.2d 1295, 1315-16 (8th Cir. 1988).

83. For an elaboration of the concept of "penalty defaults," see Ayers \& Gertner, Filling Gaps in Incomplete Contracts: An Economic Theory of Default Rules, 99 YALE L.J. 87, 95-107 (1989).

84. See A. Bickel, The Least Dangerous Branch 18 (1962). The legislative injunction does have firm foundations in various theories of judicial review. In line with process-based justifications, such as that of John Hart Ely, the beneficiaries of structural litigation tend to be exactly those persons whose interests are systematically underrepresented in a democracy-prisoners, mental patients, and black schoolchildren, for example. See J. Ely, DemocracY and Distrust (1980); see also United States v. Carolene Prods. Co., 304 U.S. 144, 152 n.4 (1938) (suggesting role for judicial review in correcting flaws in political process). Structural litigation provides remedies for those whose interests are acknowledged to require special protection from legislative action. The legislative injunction recognizes that these same people require special protection from legislative inaction, as well.

The legislative injunction also finds support in recent unapologetic defenses of judicial review as a peculiarly American democratic insight. See Ackerman, The Storrs Lectures: Discovering the Constitution, 93 YALF L.J. 1013 (1984). While the legislative branch generally constitutes the most direct measure of the people's will, in certain situations the courts must step in to assert their mandate to represent the people. In ordering remedies to constitutional violations, the courts speak with the direct authority of (We) the people. The democratic justification for protecting the legislature against the judiciary is at its weakest in such moments. The Constitution, as the highest embodiment of American democratic aspirations, overrides the will of a particular majority at a particular time. This democratic argument for judicial review gains added force when it is a local legislature (or even a local 
stances may arise in which the legislative inaction that the injunction seeks to overcome runs counter to the desire of the constituents, but the main purpose of the legislative injunction is not to remedy such flaws in the political system. ${ }^{85}$ The legislative injunction is not a substitute for electoral accountability. Rather, the legislative injunction will most commonly be employed in cases such as Jenkins, in which the legislative inaction may well represent the will of the majority. In Jenkins the legislature merely followed the preferences that the people had expressed in various popular referenda. Such a powerful counter-majoritarian tool must clearly be employed with restraint.

The Yonkers and Jenkins cases help illustrate the limits courts should observe in invoking the legislative injunction. The distinction between settled and adjudicated resolutions discussed earlier ${ }^{86}$ provides one check on judicial overreaching. Majoritarian concerns may legitimately curb a court's discretion in enforcing a remedy arising from a consent judgment that includes no finding of liability. As this Note argues, the Constitution may well require the displacement of the legislature, but only after a judicial determination of constitutional necessity. Thus, parents of schoolchildren cannot conspire with a sympathetic school board to force a legislature to increase appropriations-unless a court determines that the funds are constitutionally required.

In enforcing legislative injunctions, judges must also exercise care to respect local government structures to as great an extent as possible. While remaining committed to their remedial plans, judges should seek to avoid full-blown confrontations with local officials. In this regard, Judge Clark's plan of decreeing the desired legislative enactment, thus obviating the need to threaten the legislature with contempt sanctions or other coercive measures, seems attractive. Judge Clark would clearly have preferred that the legislature itself act. He did not dispute that appropriation decisions are best made by the people and their representatives, rather than by a judge, but he refused to let deference to legislative discretion paralyze the remedial process.

In Yonkers, Judge Sand followed the more confrontational path of forcing the legislative body to act. He sought the City Council vote for symbolic, as well as instrumental reasons. Counsel for the Yonkers branch of the National Association for the Advancement of Colored People, one of

electorate) that seeks to oppose the constitutional mandate. See Amar, Of Sovereignty and Federalism, 96 YALE L.J. 1425 (1987).

85. In some instances, the Supreme Court has intervened in legislative affairs for the purpose of ensuring that members of the legislature did not thwart the representative process by such means as gerrymandering or refusing to seat legally elected legislators. See Powell v. McCormack, 395 U.S. 486 (1969) (barring House of Representatives from excluding elected Congressman); Bond v. Floyd, 385 U.S. 116 (1966) (barring Georgia House of Representatives from excluding elected legislator); Baker v. Carr, 369 U.S. 186 (1962) (affirming justiciability of challenge to state apportionment plan).

86. See supra text accompanying notes $36-44$. 
the plaintiffs in the case, urged Judge Sand to displace the City Council and to appoint a special commission to implement the housing plan rather than to impose contempt sanctions. ${ }^{87}$ Judge Sand nevertheless persisted in seeking compliance by the Council. Defending this decision, Judge Sand cited a "philosophical or symbolic" justification for his action:

[T] here does have to come a moment of truth, a moment of reckoning, a moment when the City of Yonkers seeks not to become the national symbol of defiance to civil rights and to heap shame upon shame upon itself, but to recognize its obligation to conform to the laws of the land and not step by step, order by order, but in the way in which any responsible community concerned about the welfare of its citizens functions. ${ }^{88}$

Judge Sand may well have been justified in seeing the capitulation of the Council as an intrinsic part of the process of removing racial discrimination in Yonkers. The conduct of the Council members certainly did challenge the authority of a Federal court in a manner reminiscent of the early school desegregation cases, if on a much smaller scale. Nevertheless, the idea of jailing legislators because they refuse to vote in a particular manner conflicts with deeply held democratic values, as was apparent from the tremendous public attention the Yonkers case received. The large contempt fines levied on the city, which eventually succeeded in coercing passage of the required legislation, raise additional policy questions. By threatening their jobs and services, Judge Sand, in effect, forced the people of Yonkers into obedience. The result of noncompliance was a kind of group punishment. The Yonkers contempt sanctions probably came close to the boundary where coercive measures become in fact the sort of punitive sanctions impermissible in a civil contempt adjudication. ${ }^{89}$ Whatever the merits of Judge Sand's actions in Yonkers, it will clearly be only the rare case in which this use of enormous contempt sanctions will prove desirable. More often, circumventing the legislative process will prove more efficient and more equitable. It is one thing to place the principles of

87. See N.Y. Times, July $31,1988, \S 12 \mathrm{WC}$ (Westchester Weekly), at 1, col. 1 . If a party fails to perform an act ordered by a court, the Federal Rules of Civil Procedure allow a judge to order the act to be performed by another person with the same legal effect as if done by the party:

If a judgment directs a party ... to perform any . . . specific act and the party fails to comply within the time specified, the court may direct the act to be done . . . by some other person appointed by the court and the act when so done has like effect as if done by the party. FED. R. Civ. P. 70.

88. United States v. Yonkers Bd. of Educ., No. 80-6761 (S.D.N.Y Aug. 2, 1988) (contempt hearing).

89. See, e.g., Penfield Co. v. SEC, 330 U.S. 585, 590 (1947) (civil contempt fines must be coercive, not punitive). Concern about the size of the fines led the Second Circuit to modify Judge Sand's scheme so that the City's fines would double each day, but only up to a maximum level of one million dollars per day. United States v. City of Yonkers, 856 F.2d 444, 460 (2d Cir. 1988), cert. denied, 109 S. Ct. 1339 (1989). 
the Constitution above the current will of the majority; it is another matter to try to change that will by contempt orders.

\section{Affirmative Duties in an Activist State}

Commentators sometimes distinguish between a "negative" and a "positive" conception of constitutional rights. ${ }^{90}$ The negative view insists that the Constitution seeks to protect individual freedom by shielding the citizen from government overreaching. This conception emphasizes the danger of the legislature's meddling in affairs beyond the scope of its legitimate authority. As one nineteenth-century source expresses this sentiment, "No man's life, liberty or property are safe while the Legislature is in session." ${ }^{\text {"91 }}$ A more recent statement of the negative rights position appears in an opinion by Judge Posner of the Seventh Circuit: "[T]he Constitution is a charter of negative rather than positive liberties. The men who wrote the Bill of Rights were not concerned that Government might do too little for the people but that it might do too much to them." rights theorists, by contrast, find in the Constitution a mandate for government intervention to secure individual liberty. They argue for an affirmative government obligation to provide for basic needs, such as education and a minimum income. ${ }^{93}$

The Supreme Court has recognized positive government duties in certain situations. ${ }^{\text {94 }}$ The Court, for example, has determined that the Sixth Amendment ${ }^{95}$ provides an affirmative right to be represented by counsel and a concomitant positive duty to provide legal assistance to indigent defendants. ${ }^{96}$ The Court has also ruled that a state has an obligation to provide means for parties to protect their constitutional rights. In Truax $v$. Corrigan,${ }^{97}$ the Court held that a state could not prohibit injunctions against striking workers, since to do so would be to leave owners unable to vindicate the right of free access to their property. As these cases illustrate, however, the Supreme Court has generally inferred affirmative obligations

90. For a discussion of the distinction between positive and negative rights, see I. BERLIN, Two Concepts of Liberty, in Four Essays on LiBerTy 118 (1969); Currie, Positive and Negative Constitutional Rights, 53 U. CHI. L. Rev. 864, 864-67 (1986); Michelman, The Supreme Court, 1985 Term-Foreword: Traces of Self-Government, 100 HARv. L. REv. 4, 24-26 (1986).

91. The Final Accounting in the Estate of A.B., 1 Tucker (N.Y. Sur. Rep.) 247, 249 (1866), quoted in Starkman, State Legislators, Speech or Debate, and the Search for Truth, 11 Lor. U. CHI. L.J. 69,69 (1979).

92. Jackson v. City of Joliet, 715 F.2d 1200, 1203 (7th Cir.) (citations omitted) (Posner, J.), cert. denied, 465 U.S. 1049 (1984).

93. See, e.g., Michelman, The Supreme Court, 1968 Term-Foreword: On Protecting the Poor Through the Fourteenth Amendment, 83 HARv. L. Rev. 7, 7-19 (1969); Michelman, Welfare Rights in a Constitutional Democracy, 1979 WASH. U.L.Q. 659.

94. See Currie, supra note 90.

95. "In all criminal prosecutions, the accused shall enjoy the right . . . to have the Assistance of Counsel for his defence." U.S. ConST. amend. VI.

96. See Gideon v. Wainwright, 372 U.S. 335 (1963).

97. 257 U.S. 312 (1921). 
only in areas already defined by some level of government coercion. Decisions finding affirmative rights could often be interpreted as merely ensuring the fairness of governmental deprivations of liberty. The Court's decision this past Term in Deshaney v. Winnebago County Department of Social Services ${ }^{\mathbf{8}}$ reaffirmed a negative rights view, at least in the due process context: "[O]ur cases have recognized that the Due Process Clauses generally confer no affirmative right to governmental aid, even where such aid may be necessary to secure life, liberty, or property interests of which the government itself may not deprive the individual."99

This Note has considered the use of the legislative injunction in the remedy phase of constitutional litigation. Yonkers and Jenkins illustrate that while the legislative injunction seeks to enforce affirmative legislative duties, its legitimacy does not depend upon a theory of positive constitutional rights. In accordance with a negative understanding of rights, the legislative injunction may function simply to protect individuals against unjust government coercion. In Yonkers and Jenkins, government officials had engaged in racial discrimination, and legislative action was required to reverse the effects of this prior wrongdoing. However broadly one views the mandate for state action, the government certainly has an obligation to rectify its own improper acts.

The insight motivating the legislative injunction-that inaction does not constitute a privileged mode of government conduct-does suggest, though, the weakness of the negative rights model. The courts in Jenkins and Yonkers had explicitly held that the existing patterns of school segregation resulted from illegitimate state action. But state power is already implicated in any existing social setting. ${ }^{100}$ To understand the Constitution as a shield against government interference is to naturalize the status quo, preferring the beneficiaries of past state intervention to the petitioners of the present. Especially in the wake of the New Deal and the increasingly activist character of the modern administrative state, it is disingenuous for government to deny responsibility for the current distribution of resources. ${ }^{101}$ Since common law baselines represent prior exercises of state power, not neutral, apolitical starting points, the insistence of the negative rights model that it is government action, not inaction, that threatens individuals' liberty rings false. ${ }^{102}$ The lessons of Yonkers and Jenkins have

98. 109 S. Ct. 998 (1989).

99. Id. at 1003 .

100. See Gordon, Critical Legal Histories, 36 StAN. L. REv. 57, 103 (1984) ("[I]n practice, it is just about impossible to describe any set of 'basic' social practices without describing the legal relations among the people involved-legal relations that don't simply condition how the people relate to each other but to an important extent define the constitutive terms of the relationship .....").

101. See Sunstein, Constitutionalism and the New Deal, 101 HARv. L. REv. 421, 501-04 (1987).

102. As Sunstein explains,

The debate over "positive" and "negative" rights . . . depends on the choice of baselines. Whether a right is "positive" or "negative" turns out largely to depend on whether it calls for alterations in existing practices. The selection of such baselines has been particularly critical in 
broad application: Courts cannot permit government inaction to preserve the pernicious effects of prior government activity.

Whatever the terms employed to describe the contemporary understanding of the role of rights in regulating the interaction of individuals and the state, it is clear that legislative inaction should have no privileged place. Recognizing the theoretical limitations of the negative rights model, courts may discover unconstitutional legislative inaction in less obvious circumstances than the blatant and longstanding disregard for a school desegregation remedy. If courts take a more expansive view of the rights protected by the Constitution, conflicts between courts and legislatures may escalate. In addition to helping to demonstrate the limitations of the negative conception of rights, then, the legislative injunction may also become an increasingly important constitutional tool.

\section{CONCLUSION}

Over the past twenty-five years, structural litigations have sought to protect those who require affirmative governmental action to prevent the deprivation of their life, liberty, or property. As a result of this development, an anomaly has arisen in that the vindication of constitutional rights may seem to depend on the will of the majority as expressed through the legislature. This appearance must be deceptive, since it is the very nature of rights that they do not depend on the current preferences of the people, that they stand above the vagaries of majority rule. In sum, a fundamental aspect of constitutional rights is that they are not subject to legislative discretion. By employing the legislative injunction to guarantee constitutional rights, judges are thus not usurping legislative authority. Rather, they are creating a new, constitutional baseline, so that the legislators' exercise of discretion, be it through action or inaction, will not exceed their prerogative by violating constitutional guarantees. It is basic to the American constitutional system that legislative power is limited. The legislative injunction ensures that these limits are set not by the status quo, but by the Constitution.

cases involving the imposition of "affirmative" duties on government. The protection of the trespass laws is thus generally perceived as a negative guarantee, whereas protection of welfare rights is viewed as a positive one. Distinctions of this sort turn not on a genuine inquiry into the negative or positive character of the rights, but on whether they require the government to depart from common law categories.

Id. at 503 (footnote omitted). 